\title{
Constitutive activation of glycogen synthase kinase-3 $\beta$ correlates with better prognosis and cyclin-dependent kinase inhibitors in human gastric cancer
}

Yu Jin Cho ${ }^{1 \dagger}$, Ji Hun Kim ${ }^{2+}$, Jiyeon Yoon ${ }^{1}$, Sung Jin Cho ${ }^{1}$, Young San Ko ${ }^{1}$, Jong-Wan Park ${ }^{3}$, Hye Seung Lee ${ }^{4}$, Hee Eun Lee ${ }^{5}$, Woo Ho Kim ${ }^{5}$, Byung Lan Lee ${ }^{1,6,7^{*}}$

\begin{abstract}

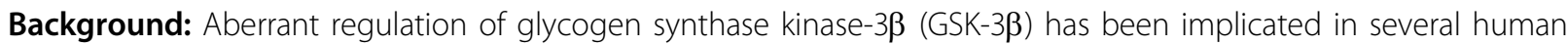
cancers; however, it has not been reported in the gastric cancer tissues to date. The present study was performed

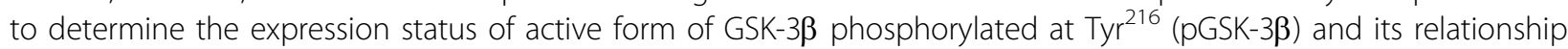
with other tumor-associated proteins in human gastric cancers.

Methods: Immunohistochemistry was performed on tissue array slides containing 281 human gastric carcinoma specimens. In addition, gastric cancer cells were cultured and treated with a GSK-3ß inhibitor lithium chloride (LiCl) for immunoblot analysis.

Results: We found that pGSK-3ß was expressed in 129 (46\%) of 281 cases examined, and was higher in the earlystages of pathologic tumor-node-metastasis $(P<0.001)$. The expression of pGSK-3 $\beta$ inversely correlated with lymphatic invasion $(P<0.001)$ and lymph node metastasis $(P<0.001)$ and correlated with a longer patient survival $(P<0.001)$. In addition, pGSK-3 $\beta$ expression positively correlated with that of p16, p21, p27, p53, APC, PTEN, MGMT, SMAD4, or KAl1 $(P<0.05)$, but not with that of cyclin D1. This was confirmed by immunoblot analysis using SNU668 gastric cancer cells treated with LiCl.

Conclusions: GSK-3 $\beta$ activation was frequently observed in early-stage gastric carcinoma and was significantly correlated with better prognosis. Thus, these findings suggest that GSK-3 $\beta$ activation is a useful prognostic marker for the early-stage gastric cancer.
\end{abstract}

\section{Background}

It is thought that human cancers, including gastric carcinoma, develop due to the accumulation of genetic alterations, such as oncogene activation and tumor suppressor gene loss [1-3]. Thus, it is important to identify genetic alterations that affect the behaviors of malignant tumors.

Glycogen synthase kinase- $3 \beta$ (GSK-3 $\beta$ ) is a serine/ threonine protein kinase whose activity is regulated by site-specific phosphorylation. Complete activation of

\footnotetext{
* Correspondence: dslanat@snu.ac.kr

† Contributed equally

'Department of Anatomy, Seoul National University College of Medicine, 28

Yeongon-dong, Chongno-gu, Seoul 110-799, Korea

Full list of author information is available at the end of the article
}

GSK-3 $\beta$ generally requires phosphorylation at $\mathrm{Tyr}^{216}$ and, conversely, phosphorylation at $\mathrm{Ser}^{9}$ inhibits GSK$3 \beta$ activity [4]. Although GSK-3 $\beta$ was first described as a component of the metabolic pathway for glycogen synthase regulation, it is now known that GSK-3 $\beta$ is a multi-functional kinase [5]. GSK-3 $\beta$ has more than 40 protein substrates and involved in a wide range of cellular processes, including differentiation, growth, motility and apoptosis [6].

The function of GSK-3 $\beta$ in human cancer cells has been most frequently evaluated in in vitro studies, which

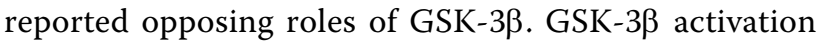
was necessary for proliferation and survival in colorectal cancer cells [7-10], ovarian cancer cells [11] and 
medullary thyroid cancer cells [12]. In contrast, GSK-3 $\beta$ activation decreased cell proliferation of breast cancer cells [13], prostate cancer cells [14], and colon cancer cells [15] as well as survival of prostate cancer cells [16], breast cancer cells [17], and colorectal cells [8]. Furthermore, in vivo xenograft studies also showed inconsistent role of GSK-3 $\beta$ in tumor promotion. Inactivated GSK$3 \beta$ promoted mammary tumorigenesis [13], whereas activated GSK-3 $\beta$ was essential for tumor growth of skin cancer [18] and medullary thyroid cancer [12]. Regarding the relation between GSK-3 $\beta$ and prognosis in human cancers, there have been few reports. GSK-3 $\beta$ expression has been correlated with a favorable outcome in squamous cell carcinoma of the tongue [19] and breast cancer [20]. In contrast, no significant correlation has been noted between GSK-3 $\beta$ and prognosis in lung cancer [21]. Thus, the biological significance of GSK-3 $\beta$ in each cancer type needs to be elucidated.

Gastric cancer is one of the most common cancers and the major cause of cancer related death worldwide [22]. Thus, a molecular understanding of the genetic factors involved in gastric cancer may contribute toward identifying novel biomarkers. To our knowledge, there are only 2 in vitro studies that showed the role of GSK$3 \beta$ in gastric cancer cells. Mai et al. (2006) showed that GSK-3 $\beta$ inhibitors (AR-A014418, SB216763) decreased proliferation and survival of gastric cancer cells [23]. In contrast, Dar et al. (2009) observed that GSK-3 $\beta$ suppression increased proliferation of gastric cancer cells [24]. Thus, the role of GSK-3 $\beta$ in gastric cancer cells still remains inconclusive. Recently, Hirakawa et al. (2009) reported the aberrant expression of GSK-3 $\beta$ in surgical gastric cancer samples [25], but they observed only 10 samples, which made it impossible to evaluate the clinicopatholoical significance of GSK-3 $\beta$ in gastric cancer.

In the present study, we extended the previous study to evaluate the expression status of active form of phos-

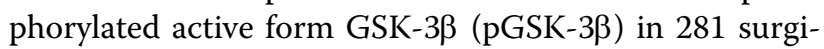
cally excised human gastric carcinoma tissues using immunohistochemical tissue array analysis. Then, the association between activated pGSK-3 $\beta$ and prognosis, clinicopathological factors or cancer-related molecule was evaluated. In addition, a gastric cancer cell line SNU-668 was treated with a GSK-3 $\beta$ inhibitor lithium chloride $(\mathrm{LiCl})$ to examine the correlation between GSK-3 $\beta$ and cyclin D1 expression.

\section{Methods}

\section{Patients}

The files of 281 surgically resected gastric cancer cases examined at the Department of Pathology, Seoul National University College of Medicine (Seoul, Korea) from January 1 to June 30, 1995 were analyzed. Age, gender, pathologic tumor-node-metastasis (pTNM) stage, lymphatic invasion, lymph node metastasis, and distant metastasis were evaluated by reviewing medical charts and pathological records. The mean age of the patients was 54.8 years, and $93.3 \%$ of the patients had undergone curative resection. The cases enrolled in this study included 217 early-stage and 64 late-stage gastric carcinomas. According to the pTNM classification, 77 cases were in stagel, 140 in stage II, 60 in stage III, and 4 in stage IV. Patients who had received preoperative chemotherapy or radiotherapy were excluded from the initial case files. The clinical outcomes of the patients were followed from the date of surgery to either the date of death or to December 31, 2004, resulting in follow-up periods ranging from 1 to 108 months (mean 35 months). Those cases lost to follow-up or those who died of any cause other than gastric cancer were regarded as censored data for the analysis of survival rates.

\section{Tissue array methods}

Six array blocks containing a total of 281 tissue cores obtained from patients with a gastric cancer were prepared by Superbiochips (Seoul, Korea) as described previously [26]. Briefly, core tissue biopsies $(2 \mathrm{~mm}$ in diameter) were taken from individual paraffin-embedded gastric tumors (donor blocks) and arranged in a new recipient paraffin block (tissue array block) using a trephine apparatus. As reported previously [27], the staining results of the different intratumoral areas of gastric carcinomas in these tissue array blocks showed excellent agreement. A core was chosen from each case for analysis. We defined an adequate case as a tumor that occupied $10 \%$ of the core area. Sections $(4 \mu \mathrm{m}$ thick) were cut from each tissue array block, deparaffinized and rehydrated. This protocol was reviewed and approved by the Institutional Review Board of Seoul National University (Approval No. C-0603-162-170).

\section{Immunohistochemistry}

Immunohistochemistry used a streptavidin peroxidase procedure after microwave antigen retrieval. Anti-phospho-GSK-3 $\beta^{\text {Tyr216 }}$ (1:50 dilution; BD Transduction Laboratories, San Diego, CA) was used as the primary antibody. Other antibodies were purchased from the following companies: anti-p16 ${ }^{\text {INK4A }}$ (1:50 dilution) and anti-retinoblastoma protein $(\mathrm{pRb})$ (1:50 dilution) from PharMingen (San Diego, CA); anti-p21 Waf1/Cip1 $(1: 100$ dilution), anti-cyclin D1 (1:500 dilution), and antiadenomatous polyposis coli (APC) (1:400 dilution), antiSMAD4 (1: 50 dilution) and anti-kangai1(KAI1) (1:200 dilution) from Santa Cruz Biotechnology (Santa Cruz, $\mathrm{CA})$; anti- $\mathrm{O}^{6}$-methylguanine DNA methyltransferase (MGMT) (1:50 dilution) from Chemicon (Temecula, 
CA); anti-p2 $7^{\text {Kip1 }}$ (1:100 dilution) from Oncogene (Cambridge, MA); anti-p53 (1:100 dilution) from DAKO Corporation (Carpinteria, CA); anti-PTEN (1:50 dilution) from A.G. Scientific Inc. (San Diego, CA); antifragile histidine triad (FHIT) (1:250 dilution) from Zymed (South SanFrancisco, CA); and von Hippel Lindau protein (pVHL) (Prediluted) from Neo Markers (Fremont, CA). Visualization was performed using 3,3'-diaminobenzidine tetrahydrochloride (Sigma, St. Louis, MO).

All immunostained sections were lightly counterstained with Mayer's hematoxylin. To confirm the specificity of each antibody, isotype matched normal serum was used as a negative control. The expression of pGSK-3 $\beta$ in the nucleus and the cytoplasm of gastric tumor cells were considered to exhibit the active form of GSK-3 $\beta$ protein. For cell cycle-related proteins, cancer cells showing nuclear staining regardless of cytoplasmic staining were regarded as expressing the proteins. The results of immunostaining were evaluated by two pathologists (JHK and WHK), who were blinded to the origin of the samples. The kappa value of pGSK-3 $\beta$ expression was $0.816(P<0.001)$. For statistical analysis of immunostaining, we initially scored the expression of activated GSK-3 $\beta$ according to the staining intensity as well as the proportion of immunoreactive tumor cells. Then, to show the results clearly, we classify the results into two categories, i.e., positive and negative. In the present study, cases showing immunoreactivity in more than $10 \%$ of the tumor cells with more than moderate intensity were considered positive, because it was most reliable cut off value in our previous experiences.

\section{Cell culture and treatment with a GSK-3 $\beta$ inhibitor}

A gastric cancer cell line SNU-668 obtained from the Korean Cell Line Bank (Seoul, Korea) was cultured in RPMI 1640 medium (Life Technologies, Inc., Grand Island, NY) containing 10\% fetal bovine serum (Life Technologies, Inc.) and maintained in a $37^{\circ} \mathrm{C}$ humidified incubator containing $95 \%$ air and $5 \% \mathrm{CO}_{2}$. To inhibit the endogenous GSK-3 3 activity, cells were treated with $30 \mathrm{mM} \mathrm{LiCl}$ for 48 hours and prepared for immunoblotting.

\section{Immunoblot analysis}

Cells were lysed with $1 \times$ Laemmli lysis buffer [2.4 M glycerol, 0.14 M Tris (pH 6.8), 0.21 M sodium dodecyl sulfate, $0.3 \mathrm{mM}$ bromophenol blue] and then boiled for 10 minutes. Protein contents were measured using BCA Protein Assay Reagent (Pierce, Rockford, IL). Samples were diluted with $1 \times$ lysis buffer containing $1.28 \mathrm{M} \beta$ mercaptoethanol, and equal amounts of protein were loaded onto $8 \%$ SDS-polyacrylamide gels. Proteins were electrophoretically transferred to nitrocellulose membranes, and membranes were then blocked with $7.5 \%$ nonfat dry milk in PBS-Tween-20 (0.1\%, v/v) at $4{ }^{\circ} \mathrm{C}$ overnight. They were then incubated with antiphospho-GSK-3 $\beta^{\text {Tyr216 }}$ (1:1000 dilution) from BD Transduction Laboratories (San Diego, CA), anti-cyclin D1 (1:1000 dilution) from Cell Signaling Technology (Beverly, MA) or anti- $\beta$-actin antibody (1:1000 dilution) from Sigma for 3 hours, and horseradish peroxidase conjugated anti-rabbit or anti-mouse IgG for 1 hour. Immunoreactive proteins were visualized by enhanced chemiluminescence (Amersham, Arlington Heights, IL).

\section{Statistical analysis}

To determine any relationship between the expressions of pGSK-3 $\beta$ and clinicopathological factors or the expressions of other proteins, either the Chi square test or the Fisher's exact test (two-sided) was performed. Survival curves were estimated using the Kaplan-Meier product-limit method, and the significance of differences between the survival curves was determined using the log-rank test. To determine if the expression of pGSK$3 \beta$ is an independent prognostic variable, multivariate survival analysis was performed using the Cox proportional hazard model. The results were considered statistically significant when $P$ values were less than 0.05 . All statistical analyses were conducted using SPSS version 12.0 statistical software program (SPSS, Chicago, IL).

\section{Results}

\section{Expression of activated pGSK-3 $\beta$}

Figure 1 shows the representative features of immunohistochemical staining of pGSK-3 $\beta$ (Figure 1A-C) and cyclin D1 (Figure 1D and E). The expression of pGSK-3 $\beta$ was shown in the nucleus and the cytoplasm of gastric tumor

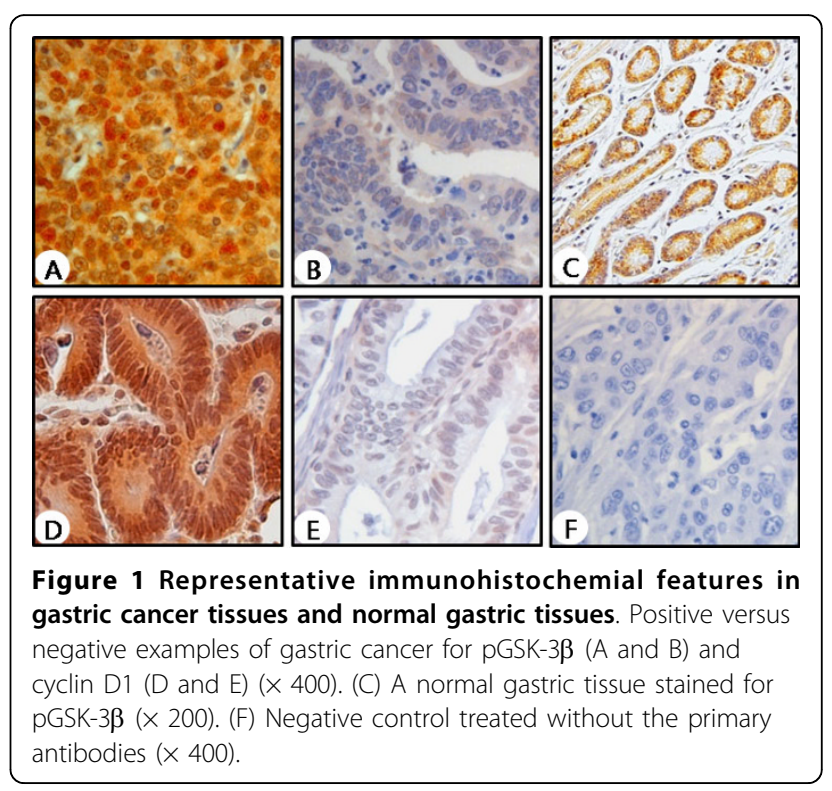


cells (Figure 1A). In normal gastric tissue, abundant expression of pGSK-3 $\beta$ was observed (Figure 1C). Immunohistochemistry for cyclin D1 showed nuclear immunoreactivity in proliferating gastric tumor cells (Figure 1D). Positive immunoreactivity of pGSK-3 $\beta$ was found in 129 (46\%) of 281 surgical gastric cancer specimens (Table 1).

\section{GSK-3 $\beta$ activation and clinicopathological features}

Data representing the correlation between activated GSK-3 $\beta$ and the clinicopathologic features of the 281 gastric cancer cases are summarized in Table 1 . The expression of pGSK-3 $\beta$ was more prevalent in the well-

Table 1 Correlation between the protein expression of pGSK-3 $\beta^{\text {Tyr216 }}$ and clinicopathological factors for 281 human gastric caicinoma specimens.

\begin{tabular}{|c|c|c|c|}
\hline & $\begin{array}{l}\text { Active GSK-3 } \beta \\
\text { Positive (\%) }\end{array}$ & $\begin{array}{c}\text { Active GSK-3 } \\
\text { Negative (\%) }\end{array}$ & $P$ value \\
\hline Total $(n=281)$ & $129(46)$ & $152(54)$ & \\
\hline \multicolumn{4}{|l|}{ Age $(y)$} \\
\hline 0-39 & $21(46)$ & $25(54)$ & 0.881 \\
\hline $40-65$ & $83(47)$ & $94(53)$ & \\
\hline $66-99$ & $25(43)$ & $33(57)$ & \\
\hline \multicolumn{4}{|l|}{ Gender } \\
\hline Male & $94(49)$ & $98(51)$ & 0.157 \\
\hline Female & $35(39)$ & $54(61)$ & \\
\hline \multicolumn{4}{|l|}{ Locus } \\
\hline Antrum & $63(42)$ & $86(58)$ & 0.230 \\
\hline Body and Cardia & $66(50)$ & $66(50)$ & \\
\hline \multicolumn{4}{|l|}{ WHO classification } \\
\hline WD & $21(78)$ & $6(22)$ & $<0.001^{*}$ \\
\hline MD & $42(53)$ & $37(47)$ & \\
\hline PD & $44(37)$ & $74(63)$ & \\
\hline \multicolumn{4}{|l|}{ Lauren's classification } \\
\hline Intestinal & $63(59)$ & $44(41)$ & $<0.001^{*}$ \\
\hline Diffuse & $62(37)$ & $107(63)$ & \\
\hline Mixed & $4(80)$ & $1(20)$ & \\
\hline \multicolumn{4}{|l|}{ TNM stage } \\
\hline I & $53(69)$ & $24(31)$ & $<0.001^{*}$ \\
\hline$\|$ & $60(43)$ & $80(57)$ & \\
\hline III & $16(27)$ & $44(73)$ & \\
\hline IV & $0(0)$ & $4(100)$ & \\
\hline \multicolumn{4}{|l|}{ Lymphatic invasion } \\
\hline Absent & $104(53)$ & $93(47)$ & $<0.001^{*}$ \\
\hline Present & $25(30)$ & $59(70)$ & \\
\hline \multicolumn{4}{|l|}{ Lymph node metastasis } \\
\hline Absent & $63(63)$ & $37(37)$ & $<0.001^{*}$ \\
\hline Present & $66(36)$ & $115(64)$ & \\
\hline \multicolumn{4}{|l|}{ Distant metastasis } \\
\hline Absent & $124(47)$ & $141(53)$ & 0.304 \\
\hline Present & $5(31)$ & $11(69)$ & \\
\hline
\end{tabular}

WD: well-differentiated adenocarcinoma; MD: moderately-differentiated adenocarcinoma; PD: poorly-differentiated adenocarcinoma.

* Considered to be statistically significant $(<0.05)$. differentiated type by WHO classification $(P<0.001)$ and in the intestinal type by Lauren's classification $(\mathrm{P}<0.001)$. In addition, the expression of pGSK-3 $\beta$ was more likely to be found in the early pTNM stages $(P<0.001)$. Eighty-eight percent of pGSK-3 $\beta$ positive tumors were in pTNM stages I and II, while $12 \%$ were in stages III and IV. Moreover, we found an inverse correlation between the expression of pGSK-3 $\beta$ and lymphatic invasion $(P<0.001)$ or lymph node metastasis $(P<0.001)$. No association was found between pGSK-3 $\beta$ expression and age, gender, tumor location or distant metastasis. These findings indicate that GSK-3 $\beta$ plays an important role in early stages of gastric cancer.

\section{GSK-3 $\beta$ activation and patient outcome}

Of the 281 patients evaluated, those with pGSK-3 $\beta$ expression had a significantly higher survival rate than those without pGSK-3 $\beta$ expression $(P<0.001$, Figure $2 A)$. These findings indicate that pGSK-3 $\beta$ expression has a significant correlation with prognosis of gastric cancer. However, multivariate Cox regression analysis including the pTNM stage revealed that the expression of pGSK-3 $\beta$ was not an independent prognostic factor. In addition, we analyzed the correlation between pGSK$3 \beta$ expression and patients' prognosis in early-stage tumors (pTNM stages I and II) and late-stage tumors (pTNM stages III and IV) separately, and found that pGSK-3 $\beta$ expression determined the survival rate in early-stage tumors $(P=0.034$, Figure $2 \mathrm{~B})$, but not in late-stage tumors $(P=0.918$, Figure $2 C)$.

\section{GSK-3 $\beta$ activation and cell-cycle regulators}

Since cell proliferation is mainly regulated by the interaction of various cell cycle regulators, we investigated the relationships between pGSK-3 $\beta$ and cell cycle regulators. Table 2 summarizes the relationship between activation of pGSK-3 $\beta$ and that of the cell cycle regulators in human gastric carcinomas. The expressions of p16, p21, p27 and p53 were statistically significantly higher in pGSK-3 $\beta$ positive gastric carcinomas than in pGSK-3 $\beta$ negative carcinomas $(P<0.001, P<0.001$, $P=0.001$, and $P=0.013$, respectively). In contrast, the expression of cyclin D1 or $\mathrm{pRb}$ showed no difference between two groups $(P=0.202$ and $P=0.208$, respectively).

\section{GSK-3 $\beta$ activation and cyclin D1 expression in gastric cancer cells in vitro}

Since the present study showed that there was no correlation between activated GSK-3 $\beta$ and cyclin D1 in clinical gastric cancer samples, we confirmed these data in the in vitro experiments using a SNU-668 gastric cancer cell line. Immunoblotting showed that the treatment of SNU-668 cells with $\mathrm{LiCl}$ decreased the expression of 


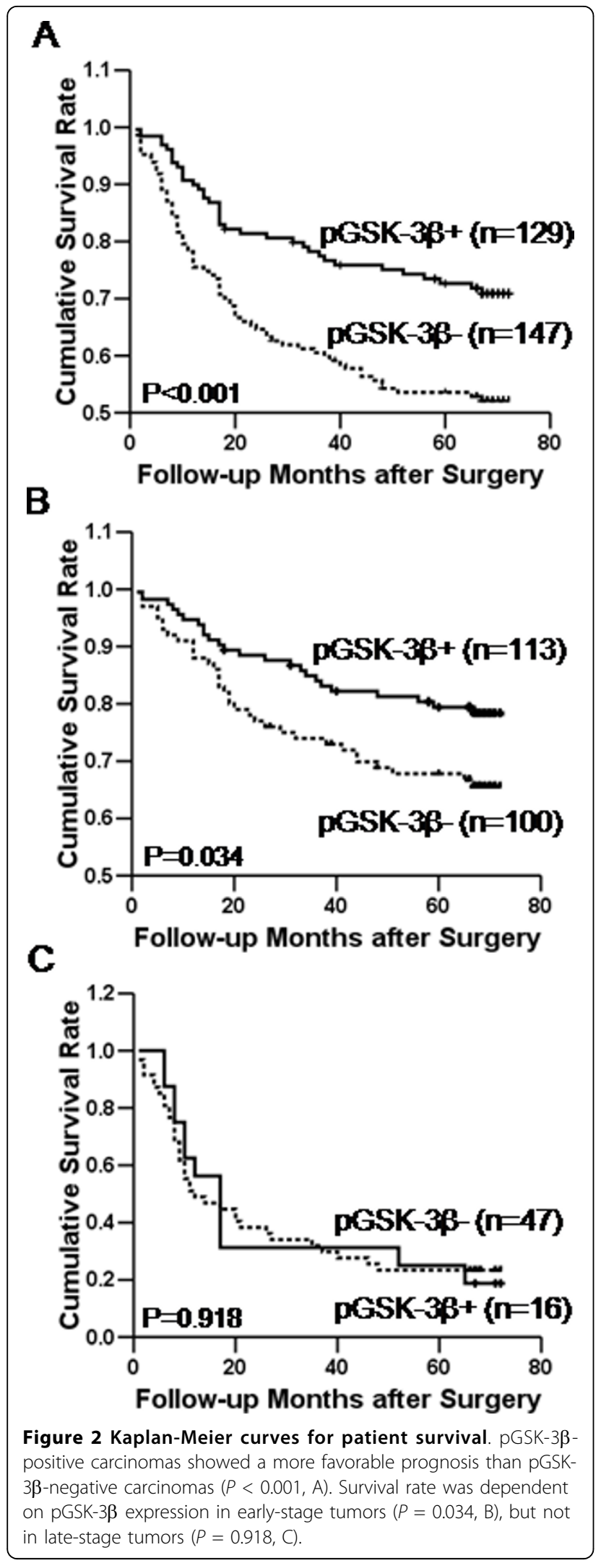

pGSK-3 $\beta$, but not that of cyclin D1 protein (Figure 3). These findings suggest that cyclin D1 expression is not regulated by activated GSK-3 $\beta$.

\section{GSK-3 $\beta$ activation and other tumor-associated proteins} The correlations between the expression of pGSK-3 $\beta$ and that of tumor suppressor gene proteins are summarized in Table 3 . The expression of pGSK-3 $\beta$ positively correlated with that of APC $(P=0.002)$, PTEN $(P=0.006)$, MGMT $(P<0.001)$, SMAD4 $(P=0.001)$, or KAI1 $(P<0.002)$. However, no association was shown between the expression of pGSK- $3 \beta$ and that of pVHL $(P=0.091)$ or FHIT $(P=0.387)$.

\section{Discussion}

The assessment of biological prognostic factors is of clinical importance, especially for a disease with poor outcome, such as gastric cancer. Since the biological significance of GSK-3 $\beta$ in gastric carcinoma remains unknown, we used a large scale tissue array-based immunohistochemistry and found that the expression of activated GSK-3 $\beta$ was positively associated with a good prognosis as well as specific clinicopathologic features in 281 human gastric carcinoma samples. We believe this is the first report on the clinical implication of activated GSK-3 $\beta$ in human gastric cancer.

Table 2 The expression of pGSK-3 $\beta^{\text {Tyr216 }}$ in relation to that of cell cycle-regulatory proteins

\begin{tabular}{|c|c|c|c|}
\hline & 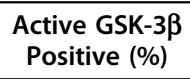 & $\begin{array}{c}\text { Active GSK-3 } \beta \\
\text { Negative (\%) }\end{array}$ & $P$ value \\
\hline \multicolumn{4}{|l|}{ p16 } \\
\hline Positive & $99(54)$ & $84(46)$ & $<0.001^{*}$ \\
\hline Negative & $24(28)$ & $63(72)$ & \\
\hline \multicolumn{4}{|l|}{ p21 } \\
\hline Positive & $38(26)$ & $39(74)$ & $<0.001^{*}$ \\
\hline Negative & $23(12)$ & $162(88)$ & \\
\hline \multicolumn{4}{|l|}{ p27 } \\
\hline Positive & $23(59)$ & $38(41)$ & $0.001^{*}$ \\
\hline Negative & $30(3)$ & $149(97)$ & \\
\hline \multicolumn{4}{|l|}{ p53 } \\
\hline Positive & $56(55)$ & $45(45)$ & $0.013^{*}$ \\
\hline Negative & $69(40)$ & $104(60)$ & \\
\hline \multicolumn{4}{|l|}{$\mathrm{pRb}$} \\
\hline Positive & $118(45)$ & $142(55)$ & 0.208 \\
\hline Negative & $6(67)$ & $3(33)$ & \\
\hline \multicolumn{4}{|l|}{ Cyclin D1 } \\
\hline Positive & $28(53)$ & $25(47)$ & 0.202 \\
\hline Negative & $90(43)$ & $119(57)$ & \\
\hline
\end{tabular}

pRb: phospho-retinoblastoma protein

* Considered to be statistically significant $(<0.05)$. 


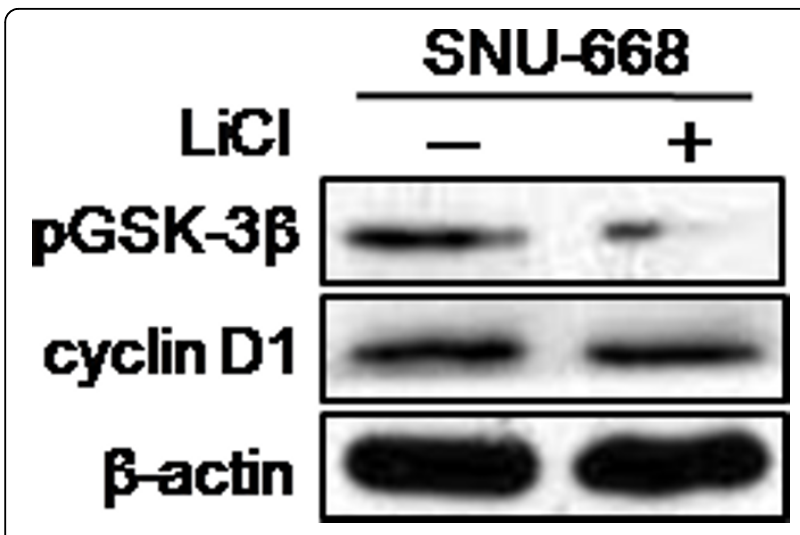

Figure 3 Protein expressions of pGSK-3 $\beta$ and cyclin D1 in SNU668 gastric cancer cells. Cells were treated with or without a GSK$3 \beta$ inhibitor $\mathrm{LiCl}(30 \mathrm{mM})$ for 48 hours and immunoblot analysis was performed for pGSK-3 $\beta$ and cyclin D1. $\beta$-actin was used as internal control.

In the present study, we performed immunohistochemical tissue array analysis using an antibody against

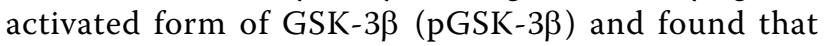
activated GSK- $3 \beta$ was expressed in $46 \%$ human gastric cancer specimens. pGSK-3 $\beta$ expression was higher in

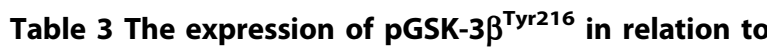
the expression of other tumor suppressor genes

\begin{tabular}{|c|c|c|c|}
\hline & $\begin{array}{l}\text { Active GSK-3 } \beta \\
\text { Positive (\%) }\end{array}$ & $\begin{array}{l}\text { Active GSK-3 } \beta \\
\text { Negative (\%) }\end{array}$ & $P$ value \\
\hline \multicolumn{4}{|l|}{ APC } \\
\hline Positive & $102(52)$ & $94(48)$ & $0.002^{*}$ \\
\hline Negative & $21(30)$ & $48(70)$ & \\
\hline \multicolumn{4}{|l|}{ PTEN } \\
\hline Positive & $105(51)$ & $103(50)$ & $0.006^{*}$ \\
\hline Negative & $17(30)$ & $40(70)$ & \\
\hline \multicolumn{4}{|l|}{ MGMT } \\
\hline Positive & $116(50)$ & $114(50)$ & $<0.001^{*}$ \\
\hline Negative & $10(25)$ & $30(75)$ & \\
\hline \multicolumn{4}{|l|}{ SMAD4 } \\
\hline Positive & $117(49)$ & $121(51)$ & $0.001^{*}$ \\
\hline Negative & $7(19)$ & $30(81)$ & \\
\hline \multicolumn{4}{|l|}{ KAl1 } \\
\hline Positive & $109(52)$ & $99(48)$ & $<0.001^{*}$ \\
\hline Negative & $17(27)$ & $47(73)$ & \\
\hline \multicolumn{4}{|l|}{$\mathrm{pVHL}$} \\
\hline Positive & $118(47)$ & $131(53)$ & 0.091 \\
\hline Negative & $7(28)$ & $18(72)$ & \\
\hline \multicolumn{4}{|l|}{ FHIT } \\
\hline Positive & $62(48)$ & $68(52)$ & 0.387 \\
\hline Negative & $56(42)$ & $77(58)$ & \\
\hline
\end{tabular}

APC: adenomatous polyposis coli; PTEN: phosphatase and tensin homologue deleted on chromosome 10; MGMT: $O^{6}$-methylguanine DNAmethyltransferase; KAl1: kangai 1; pVHL: von Hippel Lindau protein; FHIT: fragile histidine triad.

* Considered to be statistically significant $(<0.05)$ early stage tumors and was inversely associated with lymphatic invasion and lymph node metastasis. Thus, our results suggested that GSK-3 $\beta$ activation is lost during the gastric cancer progression.

There have been a number of conflicting reports concerning the prognostic implication of activated GSK-3 $\beta$ in human cancers. In the present study, we found that GSK$3 \beta$ activation significantly correlated with favorable prognosis in gastric cancer. Moreover, GSK-3 $\beta$ activation determined the survival rate in early-stage tumors $(P=0.034)$, but not in late-stage tumors. Although pTNM staging is known to have a high prognostic power in gastric cancer, it cannot predict perfectly the outcome for a particular individual. Thus, we think that GSK-3 $\beta$ activation along with pTNM staging may help predict patient outcome more accurately. Our results agreed with previous results shown in squamous cell cancer of the tongue [19] and breast cancer [20]. However, these results do not agree with those in lung cancer [21]. This discrepancy may, at least in part, comes from the differential role of GSK-3 $\beta$ in different cancer cell type as shown in earlier studies $[7-14,16-18,20]$.

Tumor growth is determined by a balance between cell proliferation and apoptosis which are linked by cell cycle-regulatory proteins. Although GSK- $3 \beta$ is known to be a key regulator of numerous signaling pathways, multiple mechanisms are involved in the regulation of cell cycle progression by GSK-3 $\beta$ [28]. The present study analyzed the relationship between GSK-3 $\beta$ activation and cell cycle regulators in gastric cancer specimens. Among the cell cycle regulators, cyclin D1 binds cyclindependent kinases (CDKs) and plays critical roles in cell cycle progression through the G1 phase [29]. Although both GSK-3 $\beta$ and cyclin D1 are known to be involved in cell cycle regulation, their relationship in cancer cells remains controversial. Activated GSK-3 $\beta$ has been shown to inhibit cyclin D1 expression in tumor cells including breast cancer cells [30] and squamous cancer cells of the tongue [19]. On the contrary, GSK-3 $\beta$ did not show any correlation with cyclin D1 expression in hepatocellular carcinoma cells [31] and fibroblasts [32]. In the present study, we found that the expression of activated GSK-3 $\beta$ was not correlated with that of cyclin D1 $(P=0.202)$ or pRB $(P=0.208)$ in surgical samples. Furthermore, treatment of gastric cancer cells with $\mathrm{LiCl}$ did not change cyclin D1 expression. Thus, our findings suggest that cyclin D1 expression in gastric cancer cells might be regulated by signaling molecules such as Ras, Nuclear factor- $\kappa \mathrm{B}$ or $\beta$-catenin rather than GSK-3 $\beta$ as previously reported [31,32].

In the present study, activated GSK-3 $\beta$ positively correlated with nuclear expression of CDK inhibitors p16 $(P<0.001)$, p21 $(P<0.001)$, and p27 $(P=0.001)$ as well as that of a tumor suppressor p53 $(P=0.013)$, but not 
with that of cyclin D1. Since the interplay between CDK inhibitors and cyclin D1-Cdk4 complex is well known, these findings seem paradoxical. However, our results are substantiated by a previous report which showed that treatment of human gastric carcinoma AGS cells with pterostilbene, an active constituent of blueberries, increased the $\mathrm{p} 53, \mathrm{p} 21, \mathrm{p} 27$, and $\mathrm{p} 16$ proteins, whereas the expression of cyclin D1 was not affected [33]. Indeed, a body of evidence accumulated now indicates that cyclin D1 exhibits CDK-independent properties in addition to its CDK-dependent function [29]. To clearly resolve this potential artifact, further molecular studies are needed.

Previously, it was reported that various tumor-suppressive genes were highly expressed in early-stage gastric carcinomas [26]. In the present study, we examined the correlation of activated GSK-3 $\beta$ with those tumor suppressor genes and found that pGSK-3 $\beta$ positively correlated with the expression of p53, APC $(P=0.002)$, PTEN $(P=0.006)$, MGMT $(P<0.001)$, Smad4 $(P=0.001)$, or KAI1 $(P<0.002)$, which were shown to be correlated with good gastric carcinoma prognosis and may act as negative regulators throughout the proliferation or progression of cancer cells [26]. In contrast, correlation was not shown between the expression of pGSK-3 $\beta$ and that of pVHL $(P=0.091)$ or FHIT $(P=0.387)$. The cellular mechanism in relation to the association between activated GSK-3 and tumor suppressive genes in early-stage gastric cancer remains to be elucidated.

\section{Conclusions}

Our results demonstrated that activated GSK-3 $\beta$ was more frequent in the early-stage gastric carcinoma, was negatively associated with nodal status, and was positively associated with better prognosis. In addition, it positively correlated with several tumor suppressor genes, including CDK inhibitors. Although further investigations are needed to clarify the molecular mechanisms involved in GSK-3 $\beta$ activation, the present findings suggest that GSK-3 $\beta$ activation plays an important role probably via inhibition of cell cycle progression, and is a candidate prognostic biomarker in gastric carcinoma.

\footnotetext{
Acknowledgements

This work was supported by grant NO 04-2009-076-0 from the SNUH Research Fund (BLL). Y.J. Cho was supported by the second stage Brain Korea 21 Project in 2006. We thank Superbiochips for their technical assistance.
}

\section{Author details}

'Department of Anatomy, Seoul National University College of Medicine, 28 Yeongon-dong, Chongno-gu, Seoul 110-799, Korea. ${ }^{2}$ Department of Pathology, Asan Medical Center, University of Ulsan College of Medicine, 388-1 Pungnap-2- dong, Songpa-gu, Seoul 138-736, Korea. ${ }^{3}$ Department of Pharmacololgy, Seoul National University College of Medicine, 28 Yeongon- dong, Chongno-gu, Seoul 110-799, Korea. ${ }^{4}$ Department of Pathology, Seoul National University Bundang Hospital, 166 Gumi-ro, Bundang-gu, Seongnamsi, Gyeonggi, 463-707 Korea. ${ }^{5}$ Department of Pathology, Seoul National University College of Medicine, 28 Yeongon-dong, Chongno-gu, Seoul 110799, Korea. ${ }^{6}$ Cancer Research Institute, Seoul National University College of Medicine, 28 Yeongon-dong, Chongno-gu, Seoul 110-799, Korea. ${ }^{7}$ Ischemic/ Hypoxic Disease Institute Medical Research Center, Seoul National University College of Medicine, 28 Yeongon-dong, Chongno-gu, Seoul 110-799, Korea.

\section{Authors' contributions}

JHK has made substantial contributions to conception and design, YJC has made substantial contributions to acquisition of data, and analysis and interpretation of data, as well as has been involved in drafting the manuscript. JY, SJC, and YSK have made substantial contributions to acquisition of data, and analysis of data. JWP, HSL, HEL and WHK have made substantial contributions to analysis and interpretation of data. BLL has been involved in drafting the manuscript and revising it critically for important intellectual content. All authors have given final approval of the version to be published.

\section{Competing interests}

The authors declare that they have no competing interests.

Received: 13 January 2010 Accepted: 12 August 2010

Published: 12 August 2010

\section{References}

1. Saegusa M, Hashimura M, Kuwata T, Hamano M, Okayasu I: Crosstalk between NF- $\kappa \mathrm{B} / \mathrm{p} 65$ and $\beta$-catenin/TCF4/p300 signalling pathways through alterations in GSK-3 $\beta$ expression during trans-differentiation of endometrial carcinoma cells. J Pathol 2007, 213(1):35-45.

2. Wu LY, Semenya KA, Hardy RE, Hargreaves MK, Robinson SB, Pederson L, Sung JF, Haynes MA: Cancer rate differentials between blacks and whites in three metropolitan areas: a 10-year comparison. J Natl Med Assoc 1998, 90(7):410-416.

3. Endoh Y, Sakata K, Tamura G, Ohmura K, Ajioka Y, Watanabe H, Motoyama T: Cellular phenotypes of differentiated-type adenocarcinomas and precancerous lesions of the stomach are dependent on the genetic pathways. J Pathol 2000, 191(3):257-263.

4. Forde JE, Dale TC: Glycogen synthase kinase 3: a key regulator of cellular fate. Cell Mol Life Sci 2007, 64(15):1930-1944.

5. Woodgett JR, Cohen P: Multisite phosphorylation of glycogen synthase. Molecular basis for the substrate specificity of glycogen synthase kinase3 and casein kinase-II (glycogen synthase kinase-5). Biochim Biophys Acta 1984, 788(3):339-347

6. Doble BW, Woodgett JR: GSK-3: tricks of the trade for a multi-tasking kinase. J Cell Sci 2003, 116(Pt 7):1175-1186.

7. Ghosh JC, Altieri DC: Activation of p53-dependent apoptosis by acute ablation of glycogen synthase kinase- $3 \beta$ in colorectal cancer cells. Clin Cancer Res 2005, 11(12):4580-4588.

8. Tan J, Zhuang L, Leong HS, Iyer NG, Liu ET, Yu Q: Pharmacologic modulation of glycogen synthase kinase- $3 \beta$ promotes $p 53$-dependent apoptosis through a direct Bax-mediated mitochondrial pathway in colorectal cancer cells. Cancer Res 2005, 65(19):9012-9020.

9. Shakoori A, Ougolkov A, Yu ZW, Zhang B, Modarressi MH, Billadeau DD, Mai M, Takahashi Y, Minamoto T: Deregulated GSK3 $\beta$ activity in colorectal cancer: its association with tumor cell survival and proliferation. Biochem Biophys Res Commun 2005, 334(4):1365-1373.

10. Shakoori A, Mai W, Miyashita K, Yasumoto K, Takahashi Y, Ooi A, Kawakami K, Minamoto T: Inhibition of GSK-3 $\beta$ activity attenuates proliferation of human colon cancer cells in rodents. Cancer Sci 2007, 98(9):1388-1393.

11. Cao $Q, L u$ X, Feng YJ: Glycogen synthase kinase-3 3 positively regulates the proliferation of human ovarian cancer cells. Cell Res 2006, 16(7):671-677.

12. Kunnimalaiyaan M, Vaccaro AM, Ndiaye MA, Chen $\mathrm{H}$ : Inactivation of glycogen synthase kinase-3 $\beta$, a downstream target of the raf- 1 pathway, is associated with growth suppression in medullary thyroid cancer cells. Mol Cancer Ther 2007, 6(3):1151-1158.

13. Farago M, Dominguez I, Landesman-Bollag E, Xu X, Rosner A, Cardiff RD, Seldin DC: Kinase-inactive glycogen synthase kinase $3 \beta$ promotes Wnt 
signaling and mammary tumorigenesis. Cancer Res 2005, 65(13):5792-5801.

14. Li Y, Wang Z, Kong D, Murthy S, Dou QP, Sheng S, Reddy GP, Sarkar FH:

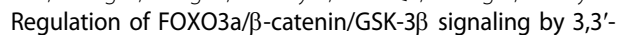
diindolylmethane contributes to inhibition of cell proliferation and induction of apoptosis in prostate cancer cells. J Biol Chem 2007, 282(29):21542-21550.

15. Wang Q, Zhou Y, Wang X, Evers BM: p27 Kip1 nuclear localization and cyclin-dependent kinase inhibitory activity are regulated by glycogen synthase kinase-3 in human colon cancer cells. Cell Death Differ 2008, 15(5):908-919.

16. Liao X, Zhang L, Thrasher JB, Du J, Li B: Glycogen synthase kinase-3 $\beta$ suppression eliminates tumor necrosis factor-related apoptosis-inducing ligand resistance in prostate cancer. Mol Cancer Ther 2003, 2(11):1215-1222

17. Soto-Cerrato V, Vinals F, Lambert JR, Kelly JA, Perez-Tomas R: Prodigiosin induces the proapoptotic gene NAG-1 via glycogen synthase kinase-3 3 activity in human breast cancer cells. Mol Cancer Ther 2007, 6(1):362-369.

18. Ma C, Wang J, Gao Y, Gao TW, Chen G, Bower KA, Odetallah M, Ding M, Ke Z, Luo J: The role of glycogen synthase kinase $3 \beta$ in the transformation of epidermal cells. Cancer Res 2007, 67(16):7756-7764.

19. Goto H, Kawano K, Kobayashi I, Sakai H, Yanagisawa S: Expression of cyclin D1 and GSK-3 3 and their predictive value of prognosis in squamous cell carcinomas of the tongue. Oral Oncol 2002, 38(6):549-556.

20. Ding Q, He X, Xia W, Hsu JM, Chen CT, Li LY, Lee DF, Yang JY, Xie X, Liu JC, Hung MC: Myeloid cell leukemia-1 inversely correlates with glycogen synthase kinase-3 3 activity and associates with poor prognosis in human breast cancer. Cancer Res 2007, 67(10):4564-4571.

21. Zheng H, Saito H, Masuda S, Yang X, Takano Y: Phosphorylated GSK3 $\beta$ ser9 and EGFR are good prognostic factors for lung carcinomas. Anticancer Res 2007, 27(5B):3561-3569.

22. Crew KD, Neugut Al: Epidemiology of gastric cancer. World J Gastroenterol 2006, 12(3):354-362.

23. Mai W, Miyashita K, Shakoori A, Zhang B, Yu ZW, Takahashi Y, Motoo Y, Kawakami $\mathrm{K}$, Minamoto $\mathrm{T}$ : Detection of active fraction of glycogen synthase kinase $3 \beta$ in cancer cells by nonradioisotopic in vitro kinase assay. Oncology 2006, 71(3-4):297-305.

24. Dar AA, Belkhiri A, El-Rifai W: The aurora kinase A regulates GSK-3 $\beta$ in gastric cancer cells. Oncogene 2009, 28(6):866-875.

25. Hirakawa H, Nakayama T, Shibata K, Sekine I: Association of cellular localization of glycogen synthase kinase $3 \beta$ in the digestive tract with cancer development. Oncol Rep 2009, 22(3):481-485.

26. Lee HS, Lee HK, Kim HS, Yang HK, Kim WH: Tumour suppressor gene expression correlates with gastric cancer prognosis. J Pathol 2003, 200(1):39-46.

27. Lee HS, Lee BL, Kim SH, Woo DK, Kim HS, Kim WH: Microsatellite instability in synchronous gastric carcinomas. Int J Cancer 2001, 91(5):619-624.

28. Holmes T, O'Brien TA, Knight R, Lindeman R, Shen S, Song E, Symonds G, Dolnikov A: Glycogen synthase kinase-3 3 inhibition preserves hematopoietic stem cell activity and inhibits leukemic cell growth. Stem Cells 2008, 26(5):1288-1297.

29. Takahashi-Yanaga F, Sasaguri T: GSK-3ß regulates cyclin D1 expression: a new target for chemotherapy. Cell Signal 2008, 20(4):581-589.

30. D'Amico M, Hulit J, Amanatullah DF, Zafonte BT, Albanese C, Bouzahzah B, Fu M, Augenlicht LH, Donehower LA, Takemaru K, Moon RT, Davis R, Lisanti MP, Shtutman M, Zhurinsky J, Ben-Ze'ev A, Troussard AA, Dedhar S, Pestell RG: The integrin-linked kinase regulates the cyclin D1 gene through glycogen synthase kinase $3 \beta$ and CAMP-responsive elementbinding protein-dependent pathways. J Biol Chem 2000, 275(42):32649-32657.

31. Gotoh J, Obata M, Yoshie M, Kasai S, Ogawa K: Cyclin D1 over-expression correlates with $\beta$-catenin activation, but not with $\mathrm{H}$-ras mutations, and phosphorylation of Akt, GSK3 $\beta$ and ERK1/2 in mouse hepatic carcinogenesis. Carcinogenesis 2003, 24(3):435-442.

32. Yang K, Guo Y, Stacey WC, Harwalkar J, Fretthold J, Hitomi M, Stacey DW: Glycogen synthase kinase 3 has a limited role in cell cycle regulation of cyclin D1 levels. BMC Cell Biol 2006, 7:33.

33. Pan MH, Chang YH, Badmaev V, Nagabhushanam K, Ho CT: Pterostilbene induces apoptosis and cell cycle arrest in human gastric carcinoma cells. J Agric Food Chem 2007, 55(19):7777-7785.

\section{Pre-publication history}

The pre-publication history for this paper can be accessed here: http://www.biomedcentral.com/1471-230X/10/91/prepub

doi:10.1186/1471-230X-10-91

Cite this article as: Cho et al:: Constitutive activation of glycogen synthase kinase-3 $\beta$ correlates with better prognosis and cyclindependent kinase inhibitors in human gastric cancer. $B M C$ Gastroenterology 2010 10:91.

\section{Submit your next manuscript to BioMed Central and take full advantage of:}

- Convenient online submission

- Thorough peer review

- No space constraints or color figure charges

- Immediate publication on acceptance

- Inclusion in PubMed, CAS, Scopus and Google Scholar

- Research which is freely available for redistribution

Submit your manuscript at www.biomedcentral.com/submit
C Biomed Central 